\title{
The standardized Withania somnifera Dunal root extract alters basal and morphine- induced opioid receptor gene expression changes in neuroblastoma cells
}

\author{
Francesca Felicia Caputi ${ }^{*}$, Elio Acquas ${ }^{2}$, Sanjay Kasture ${ }^{3}$, Stefania Ruiu ${ }^{4}$, Sanzio Candeletti ${ }^{1 \dagger}$ and Patrizia Romualdi ${ }^{1 \dagger}$
}

\begin{abstract}
Background: Behavioral studies demonstrated that the administration of Withania somnifera Dunal roots extract (WSE), prolongs morphine-elicited analgesia and reduces the development of tolerance to the morphine's analgesic effect; however, little is known about the underpinning molecular mechanism(s). In order to shed light on this issue in the present paper we explored whether WSE promotes alterations of $\mu$ (MOP) and nociceptin (NOP) opioid receptors gene expression in neuroblastoma SH-SY5Y cells.

Methods: A range of WSE concentrations was preliminarily tested to evaluate their effects on cell viability. Subsequently, the effects of $5 \mathrm{~h}$ exposure to WSE $(0.25,0.50$ and $1.00 \mathrm{mg} / \mathrm{ml})$, applied alone and in combination with morphine or naloxone, on MOP and NOP mRNA levels were investigated.

Results: Data analysis revealed that morphine decreased MOP and NOP receptor gene expression, whereas naloxone elicited their up-regulation. In addition, pre-treatment with naloxone prevented the morphine-elicited gene expression alterations. Interestingly, WSE was able to: a) alter MOP but not NOP gene expression; b) counteract, at its highest concentration, morphine-induced MOP down-regulation, and c) hamper naloxoneinduced MOP and NOP up-regulation.

Conclusion: Present in-vitro data disclose novel evidence about the ability of WSE to influence MOP and NOP opioid receptors gene expression in SH-SY5Y cells. Moreover, our findings suggest that the in-vivo modulation of morphine-mediated analgesia by WSE could be related to the hindering of morphine-elicited opioid receptors down-regulation here observed following WSE pre-treatment at its highest concentration.
\end{abstract}

Keywords: Withania somnifera, MOP receptors, NOP receptors, SH-SY5Y cells

\section{Background}

The use of herbal preparations in folk medicine has traditionally ancient roots and since often it is not fully scientifically validated an increasing effort is currently required to bridge this gap. Accordingly, in the last decades a high number of herbal preparations with specific indications, including anti-inflammatory [1], anti-microbial [2], anti-spastic [3], anti-arrhythmic [4]

\footnotetext{
* Correspondence: francesca.caputi3@unibo.it

${ }^{\dagger}$ Equal contributors

'Department of Pharmacy and Biotechnology, Alma Mater Studiorum -

University of Bologna, Via Irnerio 48, 40126 Bologna, Italy

Full list of author information is available at the end of the article
}

and anti-depressant [5] activities, just to name a few, has been examined and their chemical composition and mechanism(s) of action have been investigated in great detail. Interestingly, instances of different therapeutic properties coexisting in the same plant have been reported, and among the most promising herbs endowed with this feature Withania somnifera Dunal has shown an exponential growth in terms of scientific interest [6-8]. The number of records in PubMed for the key word "Withania somnifera" has considerably increased from 43 between 1990 and $2000[9,10]$, to 275 in the period relative to $2000-2010[11,12]$. In addition, the 566 studies collected in the period relative to $2010-2017[13,14]$ 
(up to the time of preparation of the manuscript) represent more than half of the total 915 citations found with this key word search.

Withania somnifera, or Ashwagandha, is an evergreen shrub native of the Indian subcontinent which spontaneously grows also in the Mediterranean basin [15]. Its increasing attractiveness is mostly due to the antiinflammatory $[1,8]$ and anti-cancer $[1,6]$ properties, but also to a number of central effects related to stress [8], anxiety [16] and neurodegenerative disorders [8, 17]. In this frame, it is worth noting that Withanolides and Withaferin A, abundantly present in Withania somnifera roots, have been reported to interact with cholinergic mechanisms [18] and also with Nuclear factor-kB [19-21].

Previous studies from our and other laboratories have shown that the standardized methanolic extract of Withania somnifera roots (WSE) prevents i) the dendritic spine density reduction in the shell of nucleus accumbens of rats undergoing morphine withdrawal [22], ii) the acquisition and expression of morphine-elicited conditioned place preference [23] and iii) the development of tolerance to the analgesic effects of morphine [24]. Moreover, we recently reported that WSE, although lacking of analgesic properties on its own, prolongs the anti-nociceptive effect of morphine and counteracts the paradoxical morphine-induced hyperalgesia in CD-1 mice [25], suggesting that WSE could represent a valuable adjuvant in opioid-sparing pain therapies. In addition, we assessed the binding affinities for a number of receptors $[23,25]$ and we found that WSE shows moderate affinities for $\mathrm{GABA}_{\mathrm{A}}$ and $\mathrm{GABA}_{\mathrm{B}}$ (13 and $130 \mu \mathrm{g} / \mathrm{ml}$, respectively) as well as for opioid [ $\mu$ (MOP): $385 \mu \mathrm{g} / \mathrm{ml} ; \delta: 166 \mu \mathrm{g} / \mathrm{ml}$; к: $775 \mu \mathrm{g} / \mathrm{ml}]$ receptors.

Interestingly, the absence of analgesic activity of WSE on its own, together with its low affinity for MOP receptors, suggest that the mentioned WSE/morphine interplay [22-25] might involve molecular mechanisms different from a direct receptor interaction. In this regard, gene expression alteration has been suggested as a likely mechanism for inducing long-term neuroadaptations responsible for tolerance development [26]. Furthermore, the opioid receptor gene expression regulation is differently affected by diverse opioid ligands such as morphine, fentanyl and tapentadol [27-29] which in turn recruit different $G$ protein-coupled receptor kinase isoforms, as well as exhibit diverse tolerance profiles [29-31].

Based on these premises, the present study was designed to verify whether the behavioral outcomes deriving from the interaction between WSE and morphine $[24,25]$ might be related to changes in gene expression of MOP and/or nociceptin- opioid (NOP) receptor genes, both deeply involved in the regulation of morphine analgesic properties. Notably, a critical role has been attributed to NOP receptor in several mechanisms such as desensitization, down-regulation [32-34] and intracellular signal transduction pathways [35, 36], involved in the analgesic responses to endogenous or exogenous opioid ligands [37].

Hence, using the validated in-vitro model represented by the SH-SY5Y neuroblastoma cells expressing MOP and NOP receptors [28, 38], we aimed at evaluating whether cell exposure to different WSE concentrations affects MOP and NOP gene expression. Furthermore, since MOP and NOP mRNA levels can be altered by both morphine and naloxone [27], the effect of concomitant exposure to WSE plus morphine or naloxone was also examined.

\section{Methods \\ Cell culture}

Human SH-SY5Y neuroblastoma cells purchased from ICLC-IST (Genoa, Italy), were cultured in Dulbecco's modified Eagle medium (DMEM), supplemented with $10 \%(v / \mathrm{v})$ fetal bovine serum (FBS), 100 units $/ \mathrm{ml}$ penicillin, $100 \mu \mathrm{g} / \mathrm{ml}$ streptomycin and $2 \mathrm{mM}$ glutamine. Cells were incubated at $37{ }^{\circ} \mathrm{C}$ in a humidified atmosphere containing $5 \% \quad \mathrm{CO}_{2}$ and then were allowed to reach $80 \%$ confluence before starting treatments. For each analysis new cell sets were plated. All reagents for cell culture were purchased from Lonza (Milan, Italy).

\section{Drugs and cell culture treatments}

Morphine hydrochloride was supplied by Carlo Erba (Milan, Italy); naloxone hydrochloride was supplied by Research Biochemicals INC. (Cambridge, UK). WSE, previously authenticated (NISCAIR, New Delhi, India), was kindly provided by Natural Remedies Pvt. Ltd., Bangalore, India. All substances were dissolved in DMEM and the SH-SY5Y cells were exposed to different treatment schedules. Firstly, a range of WSE concentrations $(0.10-0.25-0.50-0.75 \mathrm{mg} / \mathrm{ml}$ and $1.00 \mathrm{mg} / \mathrm{ml})$ was tested in a cell viability assay to rule out toxic effects that might affect the interpretation of the findings.

Secondly, the effects elicited by $10 \mu \mathrm{M}$ morphine, $100 \mu \mathrm{M}$ naloxone, or by their association on MOP and NOP gene expression were evaluated (treatment A - see Table 1).

Thirdly, the alterations of MOP and NOP mRNA levels induced by $0.25 \mathrm{mg} / \mathrm{ml}, 0.50 \mathrm{mg} / \mathrm{ml}$ and $1.00 \mathrm{mg} /$ ml WSE were assessed (treatment B - see Table 1). Fourthly, the effects elicited by WSE together with morphine (treatment $\mathrm{C}$ - see Table 1) or naloxone (treatment D - see Table 1) were ascertained. 
Table 1 Cell culture treatments

\begin{tabular}{llll}
\hline Treatment & Drug & Concentration & Time \\
\hline A & Morphine & $10 \mu \mathrm{M}$ & $5 \mathrm{~h}$ \\
& Naloxone & $100 \mu \mathrm{M}$ & \\
& Naloxone (30 min before) & $100 \mu \mathrm{M}$ \\
& + & \\
& Morphine & $10 \mu \mathrm{M}$ \\
& WSE & $0.25 \mathrm{mg} / \mathrm{ml}$ \\
& & $0.50 \mathrm{mg} / \mathrm{ml}$ \\
& & $1.00 \mathrm{mg} / \mathrm{ml}$ \\
& WSE (30 min before) & $0.25 \mathrm{mg} / \mathrm{ml}$ \\
& & $0.50 \mathrm{mg} / \mathrm{ml}$ \\
& & $1.00 \mathrm{mg} / \mathrm{ml}$ \\
& & \\
& & $10 \mu \mathrm{M}$ \\
& Morphine & $0.25 \mathrm{mg} / \mathrm{ml}$ \\
& WSE & $0.50 \mathrm{mg} / \mathrm{ml}$ \\
& & $1.00 \mathrm{mg} / \mathrm{ml}$ \\
& & $100 \mu \mathrm{M}$
\end{tabular}

WSE: Withania somnifera root extract

\section{WSE extraction and high-performance liquid} chromatography (HPLC) analysis

Shade dried roots of Withania somnifera Dunal $(1 \mathrm{Kg})$ were extracted in methyl alcohol (5 L) using Soxhlet's extractor apparatus (Borosil Glass Works Ltd., Ahmedabad, India). The extraction was prolonged until the liquid in siphon tube of Soxhlet's extractor did not show any spot of extract on the thin layer chromatography plate, developed using methanol as a solvent system.

The extract was dried under vacuum below $40{ }^{\circ} \mathrm{C}$ yielding $20.1 \%$ of the extract.

Then the extract was dissolved in methyl alcohol $(10 \mathrm{mg} / \mathrm{ml})$ and subsequently characterized by an HPLC-fingerprint analysis, as certified by Natural Remedies Pvt. Ltd., with identification of the main withanolides present in the extract. This analysis, with the necessary description of the technique, has been previously reported [22]. Compounds isolated from the extract and characterized as given in the literature [39], were used as reference standard for HPLC analysis: $20 \mu \mathrm{l}$ of the mixed standard solution $(\cong 100 \mu \mathrm{g} / \mathrm{ml}$ of each Withanolide in methyl alcohol) and sample solution (10 $\mathrm{mg} / \mathrm{ml}$ in methanol). A HPLC system (Shimadzu, LC 2010 A, Japan) equipped with UV detector, autoinjector, and column oven with class VP software was used.

The stationary phase was an octadecylsilane column (Phenomenex-Luna, C18, $5 \mu \mathrm{m}, 250 \mathrm{~mm} \times 4.6 \mathrm{~mm}$ ). The mobile phase was a mixture of phosphate buffer [prepared by dissolving $0.136 \mathrm{~g}$ of $\mathrm{KH}_{2} \mathrm{PO}_{4}$ in $900 \mathrm{ml}$ of HPLC grade water and by adding $10 \%$ aqueous $\mathrm{H}_{3} \mathrm{PO}_{4}$ ( $\mathrm{pH}$ adjusted to $2.8 \pm 0.05$ ) and making the volume of $1000 \mathrm{ml}$ with water, Solvent A] and acetonitrile (Solvent B) (HPLC grade, Qualigens). The flow rate of mobile phase was maintained at $1.5 \mathrm{ml} / \mathrm{min}$ throughout the analysis and the detector wave length was kept at $227 \mathrm{~nm}$. Acetonitrile and phosphate buffer were mixed and the solvent B concentration was increased as linear gradient in the first $18 \mathrm{~min}$ from 5 to $45 \%$ and from the 18 th to 25 th min from 45 to $80 \%$.

\section{Cell viability assay}

Cell viability was measured using the MTT [3-(4,5-dimethylthiazol-2-yl)-2,5-diphenyltetrazolium bromide] assay [40]. All reagents were purchased from SigmaAldrich (Milan, Italy) unless otherwise indicated. Briefly, cells were plated on 24-well plates at a density of $3 \times 10^{4}$ cells/well, and were grown to reach $80 \%$ confluence. Cells were treated with a solution of WSE in DMEM $(0.10 \mathrm{mg} / \mathrm{ml}, 0.25 \mathrm{mg} / \mathrm{ml}, 0.50 \mathrm{mg} / \mathrm{ml}, 0.75 \mathrm{mg} / \mathrm{ml}$ and $1.00 \mathrm{mg} / \mathrm{ml}$ ), or vehicle (DMEM). After $5 \mathrm{~h}, 24 \mathrm{~h}$ or $48 \mathrm{~h}$, the culture medium was removed and replaced with fresh medium containing the MTT solution $(0.5 \mathrm{mg} /$ $\mathrm{mL}$ ) and cells were incubated in the dark at $37{ }^{\circ} \mathrm{C}$ for $3 \mathrm{~h}$. After supernatant removal, a dimethyl sulfoxide-ethanol (4:1) mixture was added to each well to dissolve formazan crystals. The optical densities (OD) were then recorded using a microplate spectrophotometer (GENios Tecan, Austria) at $590 \mathrm{~nm}$. The results were expressed as a percentage of OD values of treated cell cultures compared to vehicle-treated ones.

\section{Real-time qPCR}

After treatments, total RNA was isolated using the TRIZOL reagent (Life Technologies, Monza, Italy) according to the method of Chomczynski and Sacchi [41]. RNA integrity was checked by $1 \%$ agarose gel electrophoresis and RNA concentrations were measured by spectrophotometry (all RNA samples displayed an OD260/OD280 ratio $>1.8$ and $<2.0$ ). Total RNA was reverse transcribed with the GeneAmp RNA PCR kit (Life Technologies,) using random hexamers $(0.75 \mu \mathrm{g}$ of total RNA in a final reaction volume of $20 \mu \mathrm{l}$ ). Relative abundance of each mRNA species was assessed by real-time RT-PCR using the Syber Green gene expression Master Mix (Life Technologies) in a Step One Real-Time PCR System (Life Technologies,). All samples were run in triplicate and all data were normalized to glyceraldehyde-3phosphate dehydrogenase (GAPDH) as the endogenous reference gene. Relative expression of different gene transcripts was calculated by the Delta-Delta $\mathrm{Ct}$ (DDCt) method and converted to relative expression ratio $\left(2^{-\mathrm{DDCt}}\right)$ for statistical analysis [42]. The primers 
used for PCR amplification were designed using Primer 3 [43] and their sequences have been previously validated (see Table 2) $[28,38]$.

\section{Statistical analysis}

Data from MTT assay were statistically analysed by two-way analysis of variance (ANOVA). F-values reaching significance $(p<0.05)$ were further analyzed by Bonferroni post-hoc test. Data from gene expression were analyzed by one-way ANOVA, followed by Newman-Keuls test. Statistical analysis was performed using the Graph-Pad Prism software v. 5 (GraphPad Software, San Diego, CA, USA). Results are reported as the mean of values \pm SEM $(n /$ assay $=4)$.

\section{Results}

\section{Phytochemical analysis of WSE}

HPLC-fingerprint analysis of WSE indicated the presence of the following withanolides: withanoside-IV, withanoside- $\mathrm{V}$, withaferin-A, 12-deoxy withastramonolide, withanolide-A, and withanolide-B (Fig.1a and 1b). Their individual concentrations, expressed as $\% w / w$, are reported in the Table 3; the global content of identified withanolides in WSE was $>2.5 \% \mathrm{w} / \mathrm{w}$.

\section{MTT assay for cell viability}

SH-SY5Y cells exposed to WSE showed not significant alterations of cell survival following $5 \mathrm{~h}$ (Table 4). On the contrary, 24 and $48 \mathrm{~h}$ of exposure caused a dosedependent cell viability reduction which appeared more pronounced overtime (Table 4). Two-way ANOVA revealed a significant time $\times$ treatment interaction $\left[\mathrm{F}_{(10,51)}=8.23 ; p<0.0001\right]$. Since 24 and $48 \mathrm{~h}$ exposure to WSE significantly decreased SH-SY5Y viability; these time-points were excluded from the subsequent gene expression analyses that were, accordingly, conducted following $5 \mathrm{~h}$ exposure only.

\section{MOP and NOP gene expression analysis Treatment a: Morphine and naloxone induce opposite effects on MOP and NOP gene expression}

A significant MOP gene expression down-regulation was observed following $5 \mathrm{~h}$ of $10 \mu \mathrm{M}$ morphine exposure $(0.17 \pm 0.01$ vs vehicle $1.00 \pm 0.11, p<0.01$; Fig. 2a). Conversely, $100 \mu \mathrm{M}$ naloxone induced a significant MOP mRNA increase $(2.27 \pm 0.25$ vs vehicle $1.00 \pm 0.11$, $p<0.001$; Fig. 2a). The co-exposure to morphine and naloxone did not change MOP gene expression compared to vehicle (Fig. 2a); however, the effects induced by morphine or naloxone alone were significantly different with respect to those observed after their co-exposure $(p<0.01, p<0.001$; Fig. 2a). A trend of reduction for NOP receptor gene expression was observed after morphine exposure $(0.66 \pm 0.03$ vs vehicle $1.00 \pm 0.14$, $p=0.074$; Fig. 2b), whereas naloxone induced a significant NOP up-regulation $(3.10 \pm 0.39$ vs vehicle $1.00 \pm 0.14, \mathrm{p}<0.01$; Fig. 2b). NOP gene expression analysis after naloxone and morphine co-exposure did not show significant alterations compared to vehicle (Fig. 2b); however, statistically significant differences were observed between the effects induced by the coexposure and those induced by the exposure to naloxone alone $(p<0.001$; Fig. 2b).

\section{Treatment B: WSE causes selective alterations of MOP and NOP gene expression}

WSE significantly reduced MOP gene expression levels at all concentrations used $(0.25 \mathrm{mg} / \mathrm{ml} \mathrm{WSE:} 0.20 \pm 0.01$; $0.50 \mathrm{mg} / \mathrm{ml}$ WSE: $0.10 \pm 0.01 ; 1.00 \mathrm{mg} / \mathrm{ml}$ WSE: $0.43 \pm$ 0.01 vs vehicle: $1.00 \pm 0.04$, respectively, $p<0.001$; Fig. 3a). In addition, the decrease induced by $1.00 \mathrm{mg} /$ $\mathrm{ml}$ WSE was also significantly different from those induced by the doses of 0.25 and $0.50 \mathrm{mg} / \mathrm{ml}(p<0.001)$. On the contrary, no changes of NOP mRNA levels were caused by WSE at any concentration (Fig. 3b).

\section{Treatments $C$ and D: WSE modifies morphine and naloxone effects on MOP and NOP gene expression}

WSE at 0.25 and $0.50 \mathrm{mg} / \mathrm{ml}$ failed to alter the ability of $10 \mu \mathrm{M}$ morphine to decrease MOP gene expression $(0.25 \mathrm{mg} / \mathrm{ml} \mathrm{WSE}+$ morphine: $0.30 \pm 0.04 ; 0.50 \mathrm{mg} / \mathrm{ml}$ WSE + morphine: $0.26 \pm 0.03$ vs vehicle $1.00 \pm 0.05$, respectively; $p<0.001$; Fig. 4a); on the contrary, the highest WSE concentration $(1.00 \mathrm{mg} / \mathrm{ml})$ significantly obstructed the morphine-induced MOP down-regulation (Fig. 4a).

Moreover, the effects induced by $1.00 \mathrm{mg} / \mathrm{ml}$ WSE + morphine resulted significantly different from those induced by WSE at 0.25 or $0.50 \mathrm{mg} / \mathrm{ml}+$ morphine $(p<0.001$; Fig. $4 \mathrm{a})$. In contrast, WSE pre-treatment $30 \mathrm{~min}$ before morphine addition to cell cultures failed to significantly affect NOP receptor gene expression changes (Fig. $4 \mathrm{~b}$ ).

Table 2 Primer sequences used for real-time qPCR

\begin{tabular}{llll}
\hline Gene & Forward $\left(5^{\prime}-3^{\prime}\right)$ & Reverse $\left(5^{\prime}-3^{\prime}\right)$ & Product size \\
\hline MOP & ATCACGATCATGGCCCTCTACTCC & TGGTGGCAGTCTTCATCTTGGTGT & 106 \\
NOP & GGCCTCTGTTGTCGGTGTC & GTAGCAGACAGAGATGACGAGCAC & 175 \\
GAPDH & GGTCGGAGTCAACGGATT & TGGACTCCACGACGTACTCA & 281 \\
\hline
\end{tabular}

$M O P \mu$ opioid receptor, NOP nociceptin/orphanin FQ opioid peptide receptor, GAPDH glyceraldehyde-3-phosphate dehydrogenase 


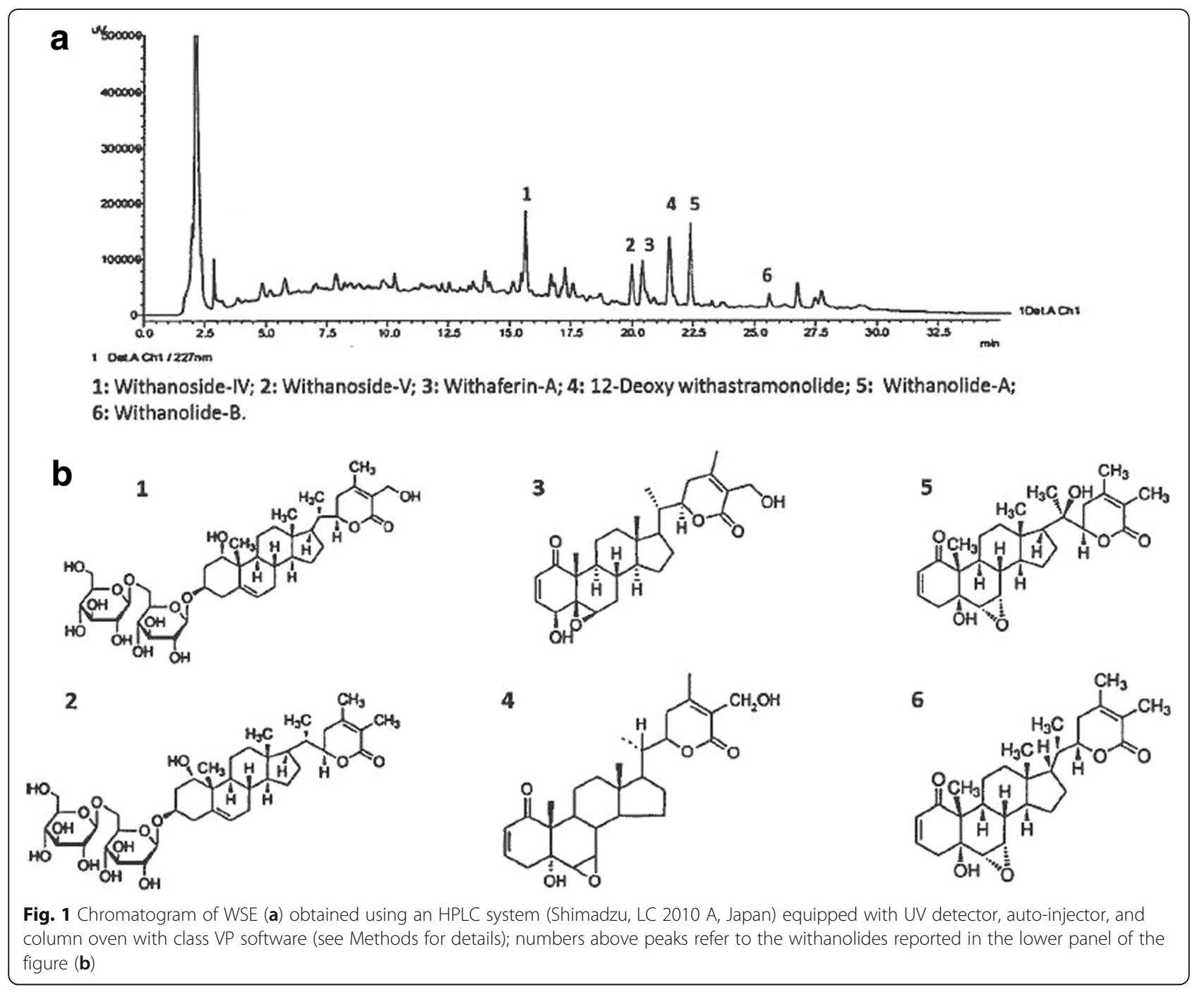

Interestingly, all WSE concentrations tested hampered the naloxone-induced MOP up-regulation, and indeed a significant decrease of MOP mRNA levels was observed resembling the effect caused by WSE alone $(0.25 \mathrm{mg} / \mathrm{ml}$ WSE + naloxone: $0.27 \pm 0.07 ; 0.50 \mathrm{mg} / \mathrm{ml} \mathrm{WSE}$ + naloxone: $0.25 \pm 0.08 ; 1.00 \mathrm{mg} / \mathrm{ml}$ WSE + naloxone: $0.55 \pm$

Table 3 Phytochemical analysis of Withania somnifera root extract by HPLC

\begin{tabular}{ll}
\hline Analyte & Concentration (\% W/W) \\
\hline a) Withanoside-IV & 0.88 \\
b) Withanoside-V & 0.47 \\
c) Withaferin-A & 0.66 \\
d) 12-Deoxy withastramonolide & 0.33 \\
e) Withanolide-A & 0.41 \\
f) Withanolide-B & 0.07 \\
Sum of withanolides conc.'s (W/W) & 2.82 \\
\hline
\end{tabular}

(Batch No.: WS/11003; Lab Reference/Report No.: FP101002)
0.07 vs vehicle $1.00 \pm 0.02$, respectively; $p<0.001$; Fig. $5 \mathrm{a}$ ). Moreover, significant differences were observed between the effects induced by naloxone $+1.00 \mathrm{mg} / \mathrm{ml} \mathrm{WSE}$ and those induced by naloxone +0.25 or $0.50 \mathrm{mg} / \mathrm{ml}$ WSE ( $p<0.05$ for both WSE concentrations; Fig. 5a).

Table 4 Effects of Withania Somnifera root extract on cell viability in the SH-SY5Y cells

\begin{tabular}{|c|c|c|c|}
\hline & \multicolumn{3}{|c|}{ Time of exposure } \\
\hline & $5 \mathrm{~h}$ & $24 \mathrm{~h}$ & $48 \mathrm{~h}$ \\
\hline Vehicle & $100.00 \pm 3.64$ & $100.00 \pm 12.62$ & $100.00 \pm 15.10$ \\
\hline $0.10 \mathrm{mg} / \mathrm{ml}$ WSE & $91.83 \pm 14.38$ & $90.52 \pm 15.53$ & $79.65 \pm 14.40$ \\
\hline $0.25 \mathrm{mg} / \mathrm{ml}$ WSE & $93.90 \pm 5.40$ & $72.63 \pm 4.16$ & $14.11 \pm 1.43^{* * *}$ \\
\hline $0.50 \mathrm{mg} / \mathrm{ml}$ WSE & $107.21 \pm 6.41$ & $49.35 \pm 3.79 * * *$ & $15.02 \pm 4.13^{* * *}$ \\
\hline $0.75 \mathrm{mg} / \mathrm{ml}$ WSE & $107.04 \pm 5.35$ & $51.73 \pm 2.69^{* * *}$ & $7.41 \pm 3.02^{* * *}$ \\
\hline $1.00 \mathrm{mg} / \mathrm{ml}$ WSE & $109.90 \pm 6.23$ & $34.69 \pm 6.29^{* * *}$ & $7.62 \pm 2.76^{* * *}$ \\
\hline
\end{tabular}

Data are expressed as mean \pm SEM (*** $p<0.001$ vs vehicle are indicated in bold) and analyzed by two-way ANOVA. F-values reaching significance $(p<0.05)$ were further analysed by Bonferroni post-hoc test 


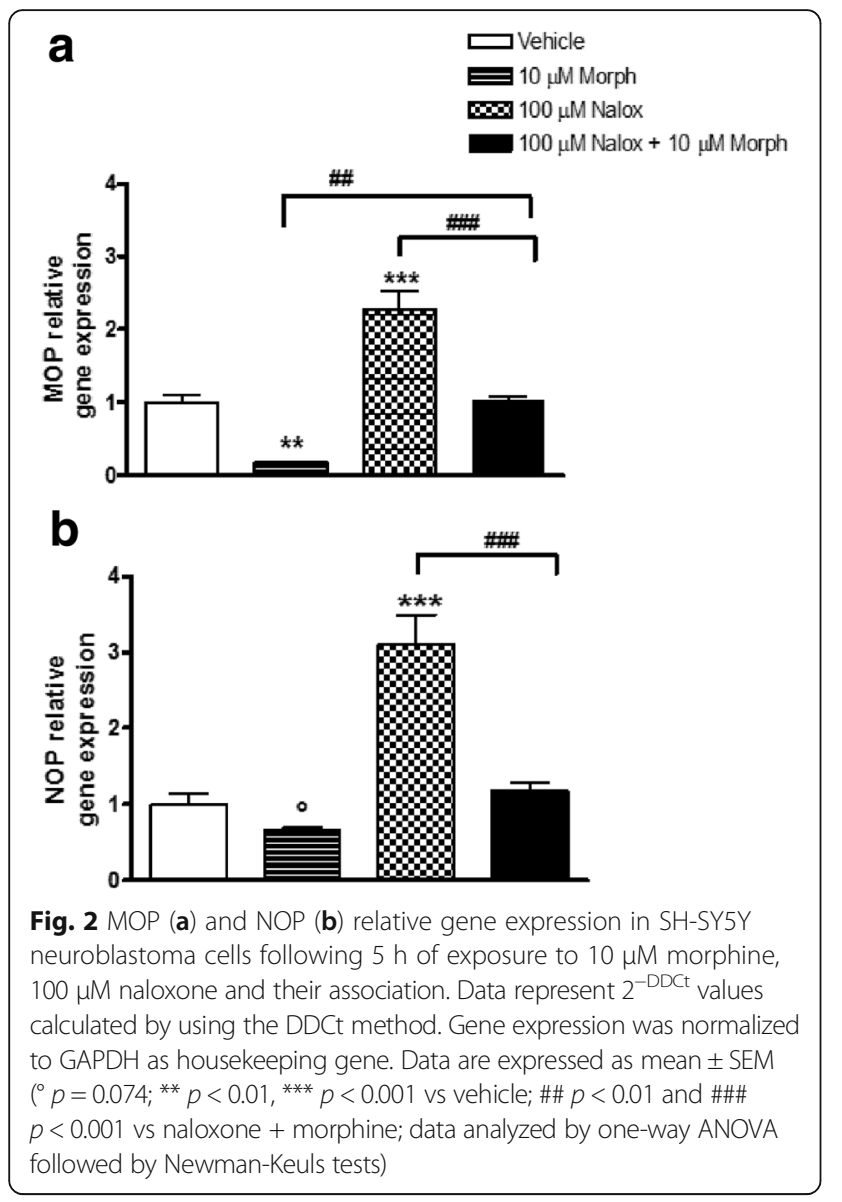

Finally, NOP receptor gene expression analysis disclosed the ability of WSE, at its lower concentrations, to prevent the naloxone-induced NOP up-regulation; on the contrary, in the presence of the highest WSE concentration, naloxone was still able to significantly up-regulate NOP gene expression $(2.20 \pm 0.32$ vs vehicle $1.00 \pm 0.10 ; p<0.01$, Fig. 5b). Statistically significant differences were observed between the effects induced by naloxone $+1.00 \mathrm{mg} / \mathrm{ml} \mathrm{WSE}$ and those induced by naloxone +0.25 or $0.50 \mathrm{mg} / \mathrm{ml}$ WSE $(p<0.01$ for both concentrations; Fig. 5b).

\section{Discussion}

The modulation of morphine analgesic effect exhibited in-vivo by Withania somnifera [24, 25] could represent an useful tool to improve the opioid-sparing strategies in pain therapy. However, little is known about how WSE can modify the molecular mechanisms leading to the development of tolerance, which represents one of the major limitations in opiate clinical use.

On these bases, since cellular adaptations responsible for tolerance development can include gene expression alterations [26], the present study investigated the effects

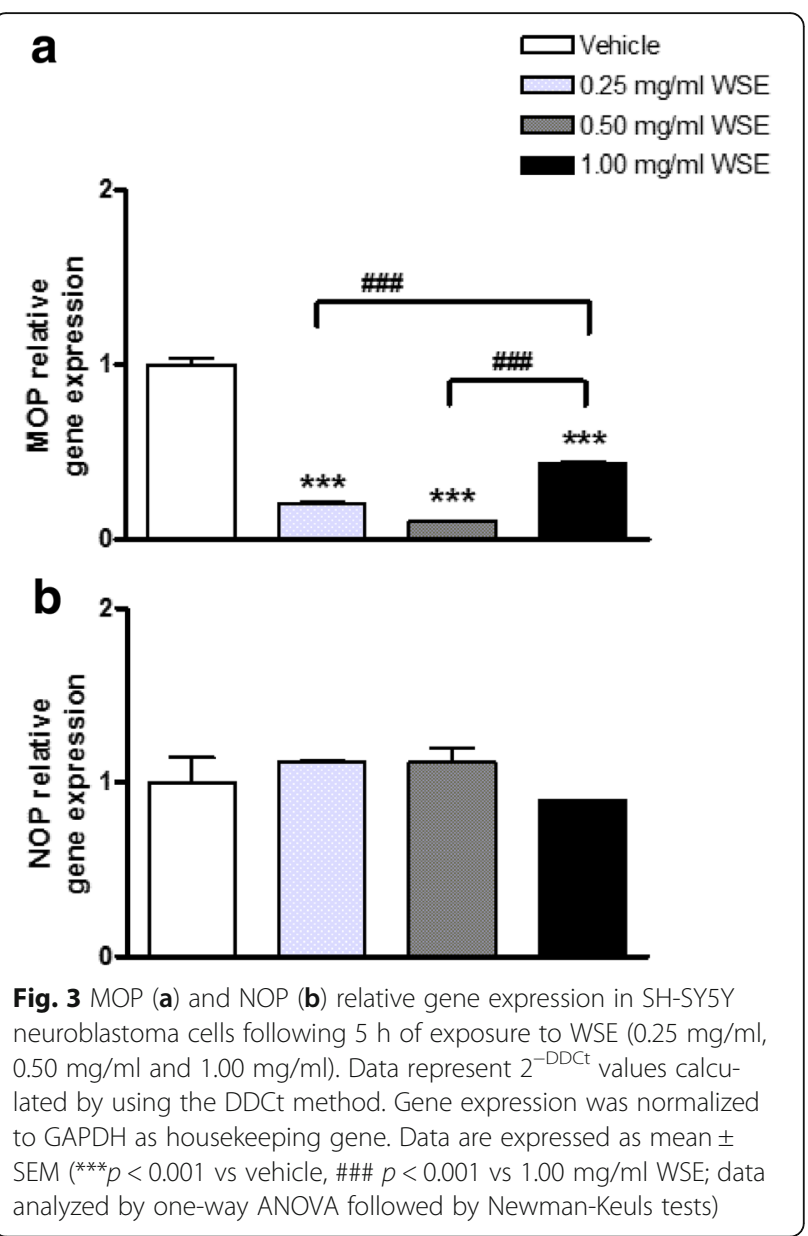

induced by WSE on the MOP and NOP receptor mRNA levels in neuroblastoma SH-SY5Y cells.

To this end, a range of WSE concentrations was tested by MTT assay showing that the concentrations of WSE examined were not cytotoxic up to $5 \mathrm{~h}$ of exposure. In contrast, the increase of the exposure time revealed a significant decrease of cell viability. Based on MTT results, $5 \mathrm{~h}$ was the interval selected to perform the gene expression analyses since at this time a general toxicity response could be ruled out in the interpretation of the findings.

The first experiment (treatment A, see Methods) showed that morphine elicited MOP gene expression down regulation and NOP receptor reduction, though not significant, whereas naloxone evoked a significant increase of their mRNA levels. The finding of morphine-induced MOP down-regulation is in agreement with previous data obtained from our [27] and other laboratories [44, 45] in SH-SY5Y, as well as in other cell lines $[46,47]$.

Our data additionally demonstrated that, in agreement with previous studies [46], morphine-induced MOP down-regulation was inhibited by naloxone pre-treatment. However, the effect of naloxone on opioid receptor gene 


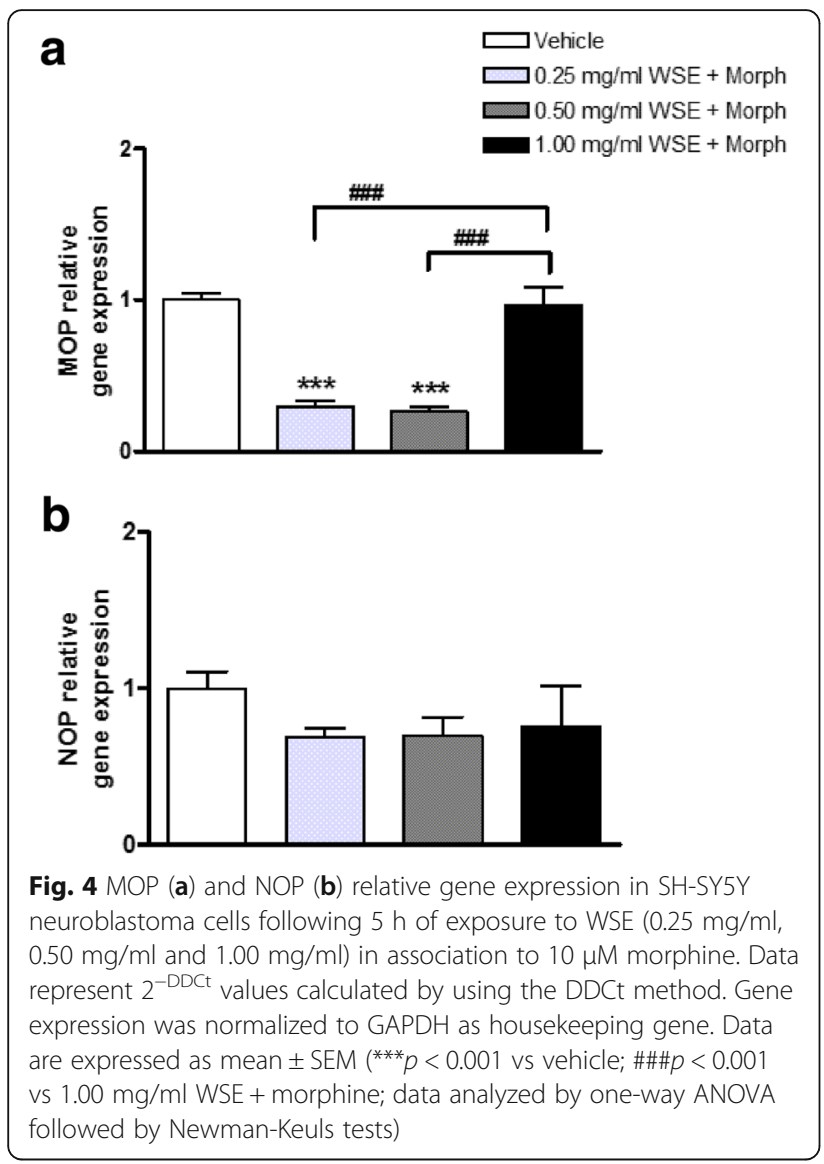

expression were not restricted to the receptor antagonism activity; in fact, naloxone alone significantly up-regulated MOP and NOP gene expression. This peculiar ability of naloxone has been observed in some previous studies. In particular, Gach et al. [46] reported that naloxone alone produced an approximately $20 \%$ increase of MOP mRNA levels as well as a $68 \%$ increase in MOP protein levels in MCF-7 cells. Moreover, the prolonged intracerebroventricular infusion of naloxone or naltrexone has been reported to cause a marked up-regulation of prodynorphin gene expression in selected rat brain areas [48].

The results of second part of the study (treatment B, see Methods), in which we tested the effects of WSE $(0.25,0.50$ and $1.00 \mathrm{mg} / \mathrm{ml})$ on the MOP and NOP gene expression indicate for the first time that WSE induced selective alterations of opioid receptor mRNA levels. In particular, we observed a significant decrease of MOP gene expression without alterations of NOP mRNA levels. Notably, the WSE-induced MOP down-regulation appeared significantly more pronounced at the lower concentrations than at the highest one. Several issues arise from these results. First, WSE clearly reduces, in a dose-independent manner, MOP mRNA levels only. It is conceivable that the different effects caused by diverse WSE concentrations might depend on the presence of
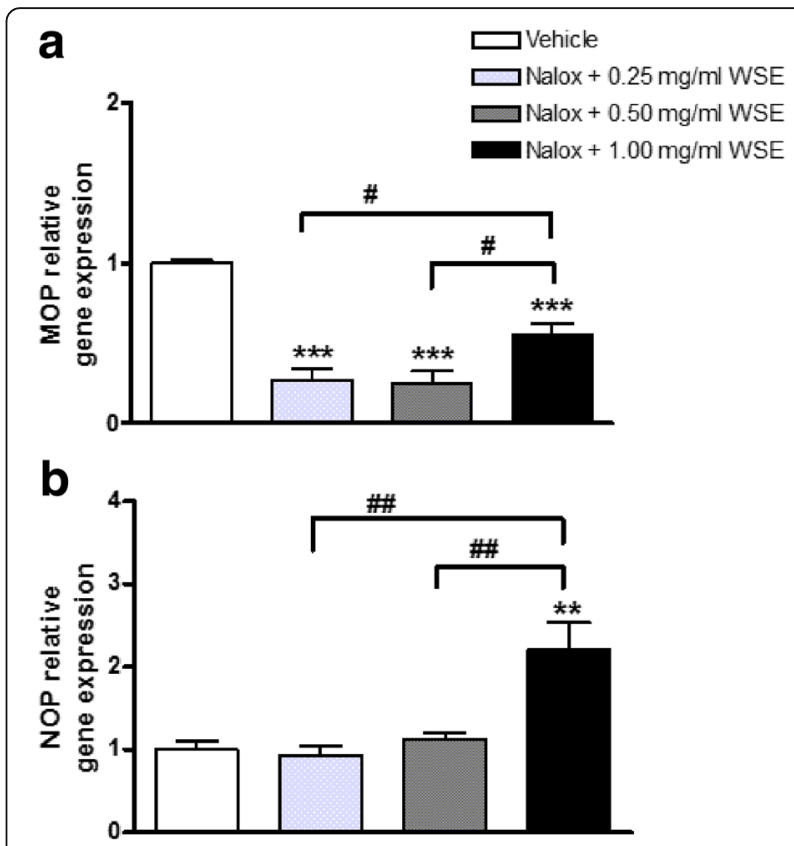

Fig. $5 \mathrm{MOP}$ (a) and NOP (b) relative gene expression in SH-SY5Y neuroblastoma cells after $5 \mathrm{~h}$ of $100 \mu \mathrm{M}$ naloxone and WSE exposure $(0.25 \mathrm{mg} / \mathrm{ml}, 0.50 \mathrm{mg} / \mathrm{ml}$ and $1.00 \mathrm{mg} / \mathrm{ml})$. Data represent $2^{-D D C t}$ values calculated by using the DDCt method. Gene expression was normalized to GAPDH as housekeeping gene. Data are expressed as mean \pm SEM (** $p<0.01,{ }^{* * *} p<0.001$ vs vehicle, $\# p<0.05$, \#\#p 0.01 vs naloxone $+1.00 \mathrm{mg} / \mathrm{ml}$ WSE; data analyzed by one-way ANOVA followed by Newman-Keuls tests)

multiple components endowed with diverse activities. In this frame, the lack of a dose-dependent effect suggests the existence of a complex interaction among the different components in the extract. In fact, WSE is a root extract containing many chemical constituents, of which 12 alkaloids and 35 withanolides $[49,50]$, responsible for its multiple medicinal properties. In this regard, it is worth considering that there are instances in which the use of isolated single constituents of an herbal preparation does not precisely reproduce the therapeutic profile of the whole extract. For example, although the antidepressant properties ascribed to the use of Hypericum perforatum (Saint John's Wort) are recognized to be mainly due to hypericin and hyperforin [51], the literature suggests caution in interpreting the results obtained following the administration of different extracts [52] or individual compounds [53], because of their peculiar pharmacokinetic and pharmacodynamic properties [52, 54].

The MOP gene expression observed after exposure to WSE could help understanding the data previously reported by Kulkarni and Ninan [24]. These authors observed the lack of morphine analgesic effect when the opiate was administered to mice that had previously received $100 \mathrm{mg} / \mathrm{kg}$ WSE for nine days. Based on our 
results, it is conceivable that morphine inefficacy could depend on MOP down-regulation induced by WSE.

A peculiar alteration of MOP gene expression emerged after treatment $\mathrm{C}$. In these experiments cells exposed to morphine following a WSE pre-treatment for a total period of $5 \mathrm{~h}$ still exhibited a significant MOP mRNA decrease after lower WSE concentrations. In contrast, at the highest WSE concentration we observed a lack of MOP receptor down-regulation, an observation that highlights the peculiar feature of this $(1.00 \mathrm{mg} / \mathrm{ml})$ WSE concentration. This result could explain how the tolerance to morphine analgesic effect was hampered when WSE $(100 \mathrm{mg} / \mathrm{kg}$ i.p.) was injected $30 \mathrm{~min}$ before morphine [24]. Therefore, based on these two observations, it can be hypothesized that the simultaneous presence of high WSE concentration and morphine could somehow be responsible of maintaining an adequate MOP receptor amount sufficient to produce the analgesic response.

The absence of NOP alterations induced by WSE alone represents an additional point of interest. In fact, previous studies suggested that MOP and NOP receptors are both involved in tolerance development. Notably, NOP receptor knockout mice display a partial loss of morphine tolerance [55]. In this frame, recent results obtained in our laboratory showed that fentanyl as well as the 14-O-Methylmorphine-6-sulfate, two potent analgesic agents endowed with lower tolerance to the analgesic effect than morphine, did not modify NOP receptor gene expression [27, 38]. Hence, since WSE pre-treatment followed by morphine exposure disclosed the potential ability of WSE to hinder the morphine-induced NOP alteration, these results could be related to a less rapid onset of morphine tolerance in the presence of WSE. In fact, the recruitment of the nociceptin/orphanin FQ (N/OFQ) - NOP system could be functional to the occurrence of morphine tolerance, and the N/OFQ antagonists may prevent tolerance development [56-58].

Finally, since we observed that opioid receptor gene expression can be increased by the competitive antagonist naloxone, we also evaluated whether WSE may influence these naloxone's effects. Results showed that WSE hampered naloxone-elicited MOP up-regulation and prevented NOP up-regulation. However, this last effect on NOP was elicited by only the lower WSE concentrations but not by the highest one thus underlining, once again, the different effect produced by WSE at its highest concentration $(1.00 \mathrm{mg} / \mathrm{ml})$.

Interestingly, G protein-coupled receptors (GPCRs), such as MOP and NOP, can adopt multiple active conformations that combine to a diverse set of downstream effectors and structurally distinct ligands can preferentially activate a subset of intracellular signaling cascades (so called biased ligands) [59]. In this regard, since WSE displays a moderate affinity for opioid receptors, it is conceivable that its interaction could interfere with the intracellular signaling triggered by the opioid ligands. Moreover, also the posttranslational control of GPCRs seems to be crucial; in fact, the gene expression regulation achievable by targeting mRNAs could be a promising candidate to coordinate the complex response to analgesic drugs [60, 61]. Additional research will be necessary to fully elucidate the opioid receptor transcriptional regulation and the downstream signaling influenced by the WSE/morphine interplay.

\section{Conclusions}

In summary, present in-vitro data suggest that the ability of WSE to affect morphine analgesic profile could take place through the gene expression regulation. In this regard, it has been hypothesized that the altered gene expression is a likely process for inducing neuroadaptations responsible for tolerance. In particular, the reduction of dendritic spine density has been correlated with the development of morphine tolerance and this neuroadaptation is regulated at gene expression level [26]. Since WSE ability to counteract morphine-induced spine density reduction upon withdrawal [22], as well as its morphine tolerance counteracting action have been demonstrated [24], it is conceivable that the mechanism by which WSE exerts these effects can include the opioid receptor gene expression regulation. In conclusion, our results showed that WSE may influence the opioid receptor gene expression and they offer new information about the complex interaction of the WSE with opioid ligands' effects on the MOP and NOP biosynthesis.

\section{Abbreviations}

DDCt: Delta-Delta threshold cycle; FBS: Fetal bovine serum; GAPDH: Glyceraldehyde-3-phosphate dehydrogenase; MOP: $\mu$ opioid receptor; MTT: [3-(4,5-dimethylthiazol-2-yl)-2,5-diphenyltetrazolium bromide]; N/OFQ: Nociception/orphanin FQ; NOP: Nociceptin/orphanin FQ opioid peptide receptor; OD: Optical densities; WSE: Withania somnifera root extract

\section{Funding}

This work was supported by grants from the University of Bologna (RFO2014 to PR) and Regione Autonoma della Sardegna (RAS) CRP 26805-CUP B71J11001480002.

\section{Availability of data and materials \\ The raw data for this study are available upon reasonable request to the corresponding author.}

\section{Authors' contributions}

FFC, EA, SR and PR conceived and designed the experiments. FFC performed the experiments. FFC and SC analyzed the data. FFC, SC, EA, SK and PR

wrote the manuscript. All authors contributed and approved the final manuscript.

Ethics approval and consent to participate Not applicable.

Consent for publication

Not applicable. 


\section{Competing interests}

The authors declare that they have no competing interests.

\section{Publisher's Note}

Springer Nature remains neutral with regard to jurisdictional claims in published maps and institutional affiliations.

\section{Author details}

'Department of Pharmacy and Biotechnology, Alma Mater Studiorum University of Bologna, Via Irnerio 48, 40126 Bologna, Italy. ${ }^{2}$ Department of Life \& Environmental Sciences, University of Cagliari, Via Ospedale, 72, 09124 Cagliari, Italy. ${ }^{3}$ Pinnacle Biomedical Research Institute, Bhopal, India. ${ }^{4}$ National Research Council (C.N.R.) - Institute of Translational Pharmacology, U.O.S. of Cagliari, Science and Technology Park of Sardinia Polaris, Pula, Italy.

Received: 14 September 2017 Accepted: 15 December 2017 Published online: 10 January 2018

\section{References}

1. Khanna D, Sethi G, Ahn KS, Pandey MK, Kunnumakkara AB, Sung B, Aggarwal A, Aggarwal BB. Natural products as a gold mine for arthritis treatment. Curr Opin Pharmacol. 2007:7:344-51.

2. Fournomiti M, Kimbaris A, Mantzourani I, Plessas S, Theodoridou I, Papaemmanouil V, Kapsiotis I, Panopoulou M, Stavropoulou E, Bezirtzoglou $\mathrm{EE}$, et al. Antimicrobial activity of essential oils of cultivated oregano (Origanum Vulgare), sage (Salvia Officinalis), and thyme (Thymus Vulgaris) against clinical isolates of Escherichia Coli, Klebsiella oxytoca, and Klebsiella Pneumoniae. Microb Eco Health Dis. 2015;26:23289.

3. Schmitz K, Barthelmes J, Stolz L, Beyer S, Diehl O, Tegeder I. "Disease modifying nutricals" for multiple sclerosis. Pharmacol Ther. 2015;148:85-113.

4. Adorisio R, De Luca L, Rossi J, Gheorghiade M. Pharmacological treatment of chronic heart failure. Heart Fail Rev. 2006;11:109-23.

5. Farahani MS, Bahramsoltani R, Farzaei MH, Abdollahi M, Rahimi R. Plantderived natural medicines for the management of depression: an overview of mechanisms of action. Rev Neurosci. 2015:26:305-21.

6. Kulkarni SK, Dhir A. Withania Somnifera: an Indian ginseng. Prog Neuropsychopharmacol. Biol Psychiatry. 2008:32:1093-105.

7. Ven Murthy MR, Ranjekar PK, Ramassamy C, Deshpande M. Scientific basis for the use of Indian ayurvedic medicinal plants in the treatment of neurodegenerative disorders: ashwagandha. Cent Nerv Syst Agents Med Chem. 2010;10:238-46.

8. Dar NJ, Hamid A, Ahmad M. Pharmacologic overview of Withania Somnifera, the Indian ginseng. Cell Mol Life Sci. 2015;72:4445-60.

9. al-Hindawi MK, al-Khafaji SH, Abdul-Nabi MH. Anti-granuloma activity of Iraqi Withania somnifera. J Ethnopharmacol. 1992;37:113-6.

10. Devi PU. Withania Somnifera Dunal (Ashwagandha): potential plant source of a promising drug for cancer chemotherapy and radiosensitization. Indian J Exp Biol. 1996:34:927-32.

11. Bhatnagar M, Sisodia SS, Bhatnagar R. Antiulcer and antioxidant activity of Asparagus Racemosus Willd and Withania Somnifera Dunal in rats. Ann N Y Acad Sci. 2005;1056:261-78.

12. Kumar S, Seal CJ, Howes MJ, Kite GC, Okello EJ. In-vitro protective effects of Withania somnifera (L.) dunal root extract against hydrogen peroxide and $\beta$-amyloid(1-42)-induced cytotoxicity in differentiated PC12 cells. Phytother Res. 2010;24:1567-74.

13. Sood A, Kumar A, Dhawan DK, Sandhir R. Propensity of Withania Somnifera to attenuate Behavioural, biochemical, and histological alterations in experimental model of stroke. Cell Mol Neurobiol. 2016;36:1123-38.

14. Choudhary D, Bhattacharyya S, Bose S. Efficacy and safety of Ashwagandha (Withania Somnifera (L.) Dunal) root extract in improving memory and cognitive functions. J Diet Suppl. 2017;14:599-612.

15. Scartezzini P, Antognoni F, Conte L, Maxia A, Troì A, Poli F. Genetic and phytochemical difference between some Indian and Italian plants of Withania Somnifera (L.) Dunal. Nat Prod Res. 2007:21:923-32.

16. Pratte MA, Nanavati $\mathrm{KB}$, Young V, Morley CP. An alternative treatment for anxiety: a systematic review of human trial results reported for the Ayurvedic herb ashwagandha (Withania Somnifera). J Altern Complement Med. 2014;20:901-8

17. Kuboyama T, Tohda C, Komatsu K. Effects of Ashwagandha (roots of Withania Somnifera) on neurodegenerative diseases. Biol Pharm Bull. 2014:37:892-7.
18. Bhattacharya SK, Kumar A, Ghosal S. Effects of glycowithanolides from Withania somnifera on animal model of Alzheimer's disease and perturbed central cholinergic markers of cognition in rats. Phytother Res. 1995;9:110-3.

19. Ichikawa H, Takada Y, Shishodia S, Jayaprakasam B, Nair MG, Aggarwal BB. Withanolides potentiate apoptosis, inhibit invasion, and abolish osteoclastogenesis through suppression of nuclear factor-KB (NF-KB) activation and NF-KB-regulated gene expression. Mol Cancer Ther. 2006:5:1434-45.

20. Maitra R, Porter MA, Huang S, Gilmour BP. Inhibition of NFkB by the natural product Withaferin a in cellular models of cystic fibrosis inflammation. J Inflamm (Lond). 2009;6:15.

21. Heyninck K, Lahtela-Kakkonen M, Van der Veken P, Haegeman G, Vanden Berghe W, Withaferin A. Inhibits NF-kappaB activation by targeting cysteine 179 in IKKß. Biochem Pharmacol. 2014;91:501-9.

22. Kasture S, Vinci S, Ibba F, Puddu A, Marongiu M, Murali B, Pisanu A, Lecca D, Zernig G, Acquas E. Withania Somnifera prevents morphine withdrawalinduced decrease in spine density in nucleus accumbens shell of rats: a confocal laser scanning microscopy study. Neurotox Res. 2009;16:343-55.

23. Ruiu S, Longoni R, Spina L, Orrù A, Cottiglia F, Collu M, Kasture S, Acquas E. Withania Somnifera prevents acquisition and expression of morphineelicited conditioned place preference. Behav Pharmacol. 2013;24:133-43.

24. Kulkarni SK, Ninan I. Inhibition of morphine tolerance and dependence by Withania Somnifera in mice. J Ethnopharmacol. 1997;57:213-7.

25. Orrù A, Marchese G, Casu G, Casu MA, Kasture S, Cottiglia F, Acquas E, Mascia MP, Anzani N, Ruiu S. Withania Somnifera root extract prolongs analgesia and suppresses hyperalgesia in mice treated with morphine. Phytomedicine. 2014;21:745-52.

26. Tapocik JD, Ceniccola K, Mayo CL, Schwandt ML, Solomon M, Wang BD, LuU TV, Olender J, Harrigan T, Maynard TM, Elmer Gl, Lee NH. MicroRNAs are involved in the development of morphine-induced analgesic tolerance and regulate functionally relevant changes in Serpini1. Front Mol Neurosci. 2016;9:20

27. Caputi FF, Lattanzio F, Carretta D, Mercatelli D, Candeletti S, Romualdi P. Morphine and fentanyl differently affect MOP and NOP gene expression in human neuroblastoma SH-SY5Y cells. J Mol Neurosci. 2013;51:532-8.

28. Caputi FF, Carretta D, Tzschentke TM, Candeletti S, Romualdi P. Opioid receptor gene expression in human neuroblastoma SH-SY5Y cells following tapentadol exposure. J Mol Neurosci. 2014;53:669-76.

29. Tzschentke TM, Christoph T, Kögel B, Schiene K, Hennies HH, Englberger W, Haurand M, Jahnel U, Cremers TI, Friderichs E, et al. (-)-(1R,2R)-3-(3dimethylamino-1-ethyl-2-methyl-propyl)-phenol hydrochloride (tapentadol $\mathrm{HCl}$ : a novel mu-opioid receptor agonist/norepinephrine reuptake inhibitor with broad-spectrum analgesic properties. J Pharmacol Exp Ther. 2007;323:265-76.

30. Grecksch G, Just S, Pierstorff C, Imhof AK, Glück L, Doll C, Lupp A, Becker A, Koch T, Stumm R, et al. Analgesic tolerance to high-efficacy agonists but not to morphine is diminished in phosphorylation-deficient S375A $\mu$-opioid receptor knock-in mice. J Neurosci. 2011;31:13890-6.

31. Glück L, Loktev A, Moulédous L, Mollereau C, Law PY, Schulz S. Loss of morphine reward and dependence in mice lacking $G$ protein-coupled receptor kinase 5. Biol Psychiatry. 2014;76:767-74.

32. Thakker DR, Standifer KM. Induction of $G$ protein-coupled receptor kinases 2 and 3 contributes to the cross-talk between mu and ORL1 receptors following prolonged agonist exposure. Neuropharmacology. 2002;43:979-90.

33. Donica CL, Awwad HO, Thakker DR, Standifer KM. Cellular mechanisms of nociceptin/orphanin FQ (N/OFQ) peptide (NOP) receptor regulation and heterologous regulation by N/OFQ. Mol Pharmacol. 2013;83:907-18.

34. Beedle AM, McRory JE, Poirot O, Doering CJ, Altier C, Barrere C, Hamid J, Nargeot J, Bourinet E, Zamponi GW. Agonist-independent modulation of N-type calcium channels by ORL1 receptors. Nat Neurosci. 2004;7:118-25.

35. Zhang NR, Planer W, Siuda ER, Zhao HC, Stickler L, Chang SD, Baird MA, Cao YQ, Bruchas MR. Serine 363 is required for nociceptin/orphanin FQ opioid receptor (NOPR) desensitization, internalization, and arrestin signaling. J Biol Chem. 2012;287:42019-30.

36. Altier C, Khosravani H, Evans RM, Hameed S, Peloquin JB, Vartian BA, Chen L, Beedle AM, Ferguson SS, Mezghrani A, Dubel SJ, Bourinet E, McRory JE, Zamponi GW. ORL1 receptor-mediated internalization of N-type calcium channels. Nat Neurosci. 2006:9:31-40.

37. Toll L, Bruchas MR, Calo' G, Cox BM, Zaveri NT. Nociceptin/Orphanin FQ receptor structure, signaling, ligands, functions, and interactions with opioid systems. Pharmacol Rev. 2016;68:419-57. 
38. Kiraly K, Caputi FF, Hanuska A, Kató E, Balogh M, Köles L, Palmisano M, Riba P, Hosztafi S, Romualdi P, Candeletti S, Ferdinandy P, Fürst S, Al-Khrasani MA. New potent analgesic agent with reduced liability to produce morphine tolerance. Brain Res Bull. 2015;117:32-8.

39. Ravi KK, Krishan AS, Rajinder KG, Naresh KS, Musarat A, Om PS, Ghulam NQ. Separation, identification, and quantification of selected withanolides in plant extracts of Withania Somnifera by HPLC-UV(DAD)-positive ion electrospray ionization-mass spectrometry. J Sep Sci. 2004;27:541-6.

40. Mosmann T. Rapid colorimetric assay for cellular growth and survival: application to proliferation and cytotoxicity assays. J Immunol Methods. 1983;65:55-63.

41. Chomczynski P, Sacchi N. The single-step method of RNA isolation by acid guanidinium thiocyanate-phenol-chloroform extraction: twenty-something years on. Nat Protoc. 2006;1:581-5.

42. Livak KJ, Schmittgen TD. Analysis of relative gene expression data usingrealtime quantitative PCR and the 2(-Delta Delta C(T)) method. Methods. 2001;25:402-8.

43. Rozen S, Skaletsky H. Primer3 on the WWW for general users and for biologist programmers. Methods Mol Biol. 2000;132:365-86.

44. Yu X, Mao X, Blake AD, Li WX, Chang SL. Morphine and endomorphins differentially regulate mu-opioid receptor mRNA in SHSY-5Y human neuroblastoma cells. J Pharmacol Exp Ther. 2003:306:447-54.

45. Mohan S, Davis RL, DeSilva U, Stevens CW. Dual regulation of mu opioid receptors in SK-N-SH neuroblastoma cells by morphine and interleukin-13: evidence for opioid-immune crosstalk. J Neuroimmunol. 2010;227:26-34.

46. Gach K, Piestrzeniewicz M, Fichna J, Stefanska B, Szemraj J, Janecka A. Opioid-induced regulation of mu-opioid receptor gene expression in the MCF-7 breast cancer cell line. Biochem Cell Biol. 2008;86:217-26.

47. Dholakiya SL, Aliberti A, Barile FA. Morphine sulfate concomitantly decreases neuronal differentiation and opioid receptor expression in mouse embryonic stem cells. Toxicol Lett. 2016;247:45-55.

48. Romualdi P, Lesa G, Donatini A, Ferri S. Long-term exposure to opioid antagonists up-regulates prodynorphin gene expression in rat brain. Brain Res. 1995;672:42-7.

49. Mishra LC, Singh BB, Dagenais S. Scientific basis for the therapeutic use of Withania Somnifera (ashwagandha) a review. Altern Med Rev. 2000;5:334-46.

50. Matsuda H, Murakami T, Kishi A, Yoshikawa M. Structures of withanosides I || III IV V VI and VII new withanolide glycosides from the roots of Indian Withania Somnifera DUNAL and inhibitory activity for tachyphylaxis to clonidine in isolated guinea-pig ileum. Bioorg Med Chem. 2001;9:1499-507.

51. Verpoorte R, Choi YH, Kim HK. Ethnopharmacology and systems biology: a perfect holistic match. J Ethnopharmacol. 2005;100:53-6.

52. Chatterjee SS, Bhattacharya SK, Wonnemann M, Singer A, Müller WE. Hyperforin as a possible antidepressant component of hypericum extracts. Life Sci. 1998;63:499-510.

53. Schmidt M, Butterweck V. The mechanisms of action of St. John's wort: an update. Wien Med Wochenschr. 2015;165:229-35.

54. Wurglics M, Schubert-Zsilavecz M. Hypericum Perforatum: a 'modern' herbal antidepressant: pharmacokinetics of active ingredients. Clin Pharmacokinet. 2006:45:449-68

55. Ueda H, Yamaguchi T, Tokuyama S, Inoue M, Nishi M, Takeshima H. Partial loss of tolerance liability to morphine analgesia in mice lacking the nociceptin receptor gene. Neurosci Lett. 1997;237:136-8.

56. Ueda $H$, Inoue $M$, Takeshima $H$, Iwasawa $Y$. Enhanced spinal nociception receptor expression develops morphine tolerance and dependence. J Neurosci. 2000:20:7640-7.

57. Zaratin PF, Petrone G, Sbacchi M, Garnier M, Fossati C, Petrillo P, Ronzoni S, Giardina GA, Scheideler MA. Modification of nociception and morphine tolerance by the selective opiate receptor-like orphan receptor antagonist (-)-cis-1-methyl-7-[[4-(26-dichlorophenyl)piperidin-1-yl]methyl]-6,7,8,9tetrahydro-5H-benzocyclohepten-5-ol(SB-612111). J Pharmacol Exp Therap. 2004;308:454-61.

58. Chung S, Pohl S, Zeng J, Civelli O, Reinscheid RK. Endogenous orphaninFQ/ nociceptin is involved in the development of morphine tolerance. J Pharmacol Exp Ther. 2006;318:262-7.

59. Wisler JW, Xiao K, Thomsen ARB, Lefkowitz RJ. Recent developments in biased agonism. Curr Opin Cell Biol. 2014;27:18-24.

60. He Y, Yang C, Kirkmire CM, Wang ZJ. Regulation of opioid tolerance by let-7 family microRNA targeting the mu opioid receptor. J Neurosci. 2010;30:10251-8.

61. He Y, Wang ZJ. Let-7 microRNAs and opioid tolerance. Front Genet. 2012;3:110.

\section{Submit your next manuscript to BioMed Central and we will help you at every step:}

- We accept pre-submission inquiries

- Our selector tool helps you to find the most relevant journal

- We provide round the clock customer support

- Convenient online submission

- Thorough peer review

- Inclusion in PubMed and all major indexing services

- Maximum visibility for your research

Submit your manuscript at www.biomedcentral.com/submit 